\title{
BRCA Rearrangement
}

National Cancer Institute

\section{Source}

National Cancer Institute. BRCA Rearrangement. NCI Thesaurus. Code C122866.

A molecular abnormality indicating the presence of rearrangement mutations in either the BRCA1 gene at $17 q 21$ or the BRCA2 gene at 13q12.3. 